\title{
KATEDRA PIOTRA W NAUCZANIU OPTATA Z MILEWY JAKO OSTATECZNY PROBIERZ PRAWDZIWOŚCI KOŚCIOLA
}

„In urbe Roma Petro primo cathedram episcopalem esse conlatam"1; to stwierdzenie św. Optata, dające wyraz przekonaniu Kościoła o tym, że katedra św. Piotra stanowi jego widzialne centrum, wprowadza nas od razu w sedno zagadnienia. Myśl ta zaczerpnięta z dzieła pisanego około 365 r. i przepracowanego dwadzieścia lat później przez Optata, kształtowana była w jakiś sposób przez rzeczywistość, która w Afryce łacińskiej od zakończenia krwawych prześladowań Dioklecjana była smutna. Obok bowiem Kościoła katolickiego pojawił się donatystyczny, $\mathrm{z}$ własnym episkopatem, schizmatyckim co prawda, ale na tyle mocnym i trwałym, by na długo rzucić cień na obraz życia i doktryny chrześcijan w Afryce ${ }^{2}$. Ponaglany koniecznością obrony Kościoła katolickiego, zagrożonego w Afryce jak nigdy dotąd, sięgnął Optat do koncepcji katedry Piotra wyraźnie wyeksponowanej w nauczaniu św. Cypriana i uczynił z niej oręż do zwalczania donatystycznego rozłamu ${ }^{3}$. Koncepcja ta, była czymś, co wyróżniało myśl afrykańską na tle innych nurtów eklezjologicznych chrześcijaństwa oscylujących wokół Rzymu jako jego centrum. Oparta na fundamencie biblijnym, a zwłaszcza na słowach Zbawiciela „Tu es Petrus”, stała na straży jedności Kościoła i czystości jego wiary. Św. Cyprian gwarancję ich zachowania

1 Optatus Milevitanus, Tractatus contra Donatistas (= Contra Donatistas) II 2, 2, ed. M. Labrousse, Paris 1995, SCh 412, 244.

${ }^{2}$ Por. T. Kolosowski, Od wolnosci wyboru wyznania do przymusu religijnego. Ewolucja poglqdów biskupa Augustyna z Hippony podczas schizmy donatystycznej w Afryce rzymskiej, Piła 2000; W.H.C. Frend, The Donatist Church. A movement of protest in Roman North Africa, Oxford 1952. W czasie redagowania traktatu przez św. Optata na dobre przyjęla się nazwa schizmy donatystycznej, o czym świadczyć może następujące zdanie: „Ausus est populum cum Deo dividere, ut qui illum secuti sunt, iam non christiani vocarentur, sed donatistae!" (Contra Donatistas III $3,15, \operatorname{SCh} 413,28-30$ ).

${ }^{3}$ Por. V. Monachino, Il primato nello scisma donatista, "Archivum Historiae Pontificiae" 2 (1964) 35; A. Zmire, Le rôle de l'évèque de Rome au sein du college Épiscopal, „Recherches Augustiniennes" 7 (1971) 3-72, spec. 36n.; P. Batiffol, Cathedra Petri, Paris 1938, 112; M. Maccarrone, Apostolicità, episcopato e primato di Pietro. Ricerche e testimonianze dal II al V secolo, „Lateranum" 42 (1976) nr 2, 220. 
widział w osobie Księcia Apostołów, na którym Zbawiciel założył katedrę. Ona, dziedziczona przez następców św. Piotra w Rzymie, jako cathedra Petri, stanowi źródło jedności Kościoła.

Dzięki sukcesji apostolskiej, także biskupi mają udział w jej dziedziczeniu, niemniej tylko biskup Rzymu jest jak Piotr głową pozostałych, a wspólnota $z$ nim jest znakiem prawowierności każdego biskupa ${ }^{4}$. Tę właśnie ideę przejął i rozwinąl Optat, i ona to stanowić będzie ukoronowanie jego argumentacji używanej $\mathrm{w}$ walce $\mathrm{z}$ donatystami. $\mathrm{W}$ traktacie skierowanym przeciwko nim dają się wyróżnić wyraźnie dwa aspekty: historyczny i teologiczny. Ich wyraźna naprzemienność wydaje się być zaplanowanym zabiegiem, jakim posłużył się autor, by dokonać analizy schizmy $z$ teologicznego punktu widzenia na bazie historycznych wydarzen $^{5}$. Analizy tej dokonuje Optat w kolejnych księgach. W I omawia początki schizmy, jej przyczyny i skutki, by w księdze II przejść do zagadnień z dziedziny doktrynalnej, wykazując, że tylko Kościół katolicki, rozpowszechniony po całym świecie, jest prawdziwy, bo zjednoczony ze stolicą św. Piotra w Rzymie ${ }^{6}$. W księdze III znowu powraca wątek historyczny w omawianiu zarówno edyktu cesarskiego o jedności, jak i wydarzeń, które po nim nastąpiły. Po dokonaniu w księdze IV niezbędnej egzegezy biblijnej dla zrozumienia pozycji grzesznika w Kościele, rozwija w następnej księdze (V) teologię chrztu, będącą kulminacyjnym punktem traktatu, a w księdze VI powraca do opisu dramatycznych wydarzeń za panowania Juliana Apostaty. Ta zamierzona naprzemienność, ujawniająca rozumowanie Optata jako historyka i teologa, miała za cel zbudowanie takiej struktury argumentacji, która byłaby lepszą od tej, jaką prezentował w swoim traktacie skierowanym przeciw katolikom główny szermierz donatyzmu Parmenian ${ }^{7}$. Zdaniem Optata, Parmenian rozpatrywał problemy teologiczne nie dbając o dostarczenie faktów stanowiących ich niezbędną, historyczną bazę. Optat zaś najpierw zamierza ustalić fakty, przeanalizować je, podeprzeć swoje dowodzenie oficjalnymi dokumentami i dopiero potem rozważać kwestie teologiczne. Nie znaczy to jednak, że trzymal się kurczowo tego schematu, bowiem w niektórych miejscach swego dzieła wprowadził pewne dygresje i antycypacje

${ }^{4}$ Por. Cyprianus, Epistula 59, 14; De catholicae Ecclesiae unitate 4; M. Maccarrone, , Cathedra Petri" e lo sviluppo dell'idea del primato papale dal II al IV secolo, w: Miscellanea Antonio Piolanti, vol. II, Romae 1964, 49.

5 Por. M. Labrousse, Optat de Milève. Traité contre les Donatistes. Introduction, SCh 412, 22.

${ }^{6}$ Por. B. Altaner - A. Stuiber, Patrologia, thum. P. Pachciarek, Warszawa 1990, 493.

${ }^{7}$ Na temat Parmeniana sam Optat tak pisze: „Omnes quidem per singula loca maledicis vocibus perstrepunt; sed unum quidem vix invenimus cum quo per litteras vel hoc modo loquamur, Parmenianum scilicet fratrem nostrum, si tamen se a nobis vel hoc nomine nuncupari permittit. Et quia collegium episcopale nolunt nobiscum habere commune, non sint collegae, si nolunt! Tamen, ut supra diximus, fratres sunt. Frater meus igitur Parmenianus, ne ventose ac nude ut ceteri loqueretur, quidquid sentire potuit non solum sixit sed etiam in scriptura digessit. Cuius dictis cum respondere veritate cogente compellimur, erit inter nos absentes quoquomodo collatio" (Contra Donatistas I 4, 1-2, SCh 412, 178), thum. pol. A. Golda, VoxP 23 (2003) t. 44-45, 444. 
mające za cel pogłębienie argumentacji teologicznej, przemawiającej na korzyść prawdziwego Kościoła ${ }^{8}$. Pozostaje jeszcze księga VII, którą około 385 r. Optat dodał do poprzednich, do których też wprowadził $w$ tym czasie uzupełnienia i zmiany. Nacisk zaś w niej położył nie na polemice, czy oskarżeniu, lecz na uzasadnieniu swojego apelu o jedność ${ }^{9}$. Było to trudne, donatyści bowiem uważali katolików wprost za zdrajców, którzy nie tylko, że wykluczają się z Kościoła, ale także są odpowiedzialni za represje, jakie spadły na rzekomo jedynie prawdziwy, czyli donatystyczny Kościól. Tymczasem Optat wyraźnie mówi, ze prawdziwy Kościół jest tam, gdzie nie przekreśla się grzesznika, gdyż tu na ziemi grzeszni mieszają się ze świętymi również w Kościele. Dopóki Chrystus nie dokona ostatecznego oddzielenia złych od dobrych, nie należy sobie uzurpować osądzania bliźniego. Takie podejście ilustruje Optat przypowieścią o plewach i ziarnie, wpisując świętość Kościoła w perspektywę eschatologiczną ${ }^{10}$. Idąc po tej linii myślenia o Kościele, nie potępia Optat wcale donatystów za to, że są synami zdrajców, lecz ponawia apel o jedność i dialog. Niestety ten apel wzywający do braterstwa i dialogu okazał się daremny, bo trafił na sekciarski upór ze strony donatystów, którzy tak naprawdę nie chcieli żadnego zbliżenia z Kościołem katolickim, uważając go za grzeszny ${ }^{11}$. Musial więc Optat chwycić się innego środka, by dowieść prawdziwości Kościoła katolickiego, otwartego zarówno na sprawiedliwych, jak i grzeszników. I znalazł go w postaci koncepcji katedry Piotra, która jest pierwszym darem danym Kościołowi. A z tego daru wypływają pozostałe, takie jak: chrzest, kapłaństwo czy dar oltarza ${ }^{12}$.

„Jest rzeczą dowiedziona, że jesteśmy w świętym Kościele katolickim, my posiadający symbol Trójcy Świętej, my, którzy posiadamy katedrę Piotra, nam przynależną. Przez ten dar posiadamy wszystkie inne dary" ${ }^{\prime 13}$.

${ }^{8}$ Por. P. Monceaux, Histoire litteraire de l'Afrique chrétienne, V, Paris 1923, gdzie na stronie 246 autor zdaje się podważać rolę Optata w opracowaniu katolickiej teologii sakramentów pisząc: „Peu porté aux spéculations, il n'a guère parlé de théologie". Tymczasem dogłębna lektura dzieła Optata podważa takie stwierdzenie, czyniąc go nieprawdziwym, zob. Y.M.J. Congar, La théologie donatiste de l'Église et des sacraments. L'apport de Saint Augustin, w: Introduction générale. Traités anti-donatistes de Saint Augustin, BA 28, Paris 1963, 25.

${ }^{9} \mathrm{Na}$ temat autentyczności księgi VII por. Monachino, art. cyt., s. 30n; także Labrousse, dz. cyt., s. 35n; o aspektach teologicznych tej księgi zob. Congar, jw., s. 156.

${ }_{10}$ Por. Contra Donatistas I 20, 3; I 21, 8; II 25, 2. 10; V 10, 1; VII 2, 1-8; zob. Labrousse, dz. cyt., s. 50 .

11 Shusznie zauważa Congar pisząc o donatystach (La théologie donatiste, s. 45): „C'est dans leur esprit męme, on dirait: dans la structure de leur esprit, que les donatistes n'étaient pas catholiques. Ils avaient l'esprit sectaire".

12 Por. Contra Donatistas II 2, 1, SCh 412, 244: „Quinque dotes [Ecclesiae]... inter quas cathedra est prima, ubi nisi sederit episcopus, coniungi altera dos non potest"; zob. E.A. Bonomo, La Chiesa sposa e le doti in Ottato di Milevi, Roma 1943.

${ }^{13}$ Contra Donatistas II 9, SCh 412, 260: „cum probatum est nos esse in ecclesia sancta catholica, apud quos et symbolum Trinitatis est, et per cathedram Petri, quae nostra est, per ipsam et ceteras dotes apud nos esse?". 
Tak przedstawiona katedra Piotra stanowi centrum życia chrześcijańskiego na równi z wyznaniem wiary, które pozostaje wyróżnikiem każdego, kto przez chrzest święty wchodzi w misterium Kościoła. By przeciwstawić się roszczeniom donatystów, którzy twierdzili, że to jedynie oni posiadają katedrę, czyli władzę kluczy, uzależniając jej autentyczność od świętości biskupów, stróżów czystości i wiary, Optat osadzil prawowitość Kościoła na jedności ze wspólnotami założonymi przez Apostołów, a szczególnie ze wspólnotą w Rzymie. Idąc za Tertulianem, który nazywa je „matrices et originales fidei”"14 , podkreśla ich znaczenie dowodząc w sposób zdecydowany, że gwarancją ich autentyczności jest nieprzerwana sukcesja biskupów, następców Apostołów. Tą sukcesją nie mogą w żaden sposób pochwalić się donatyści, bo sięga ona u nich najwyżej poprzednika. Słusznie więc nazwać można sprawowaną przez nich władzę jako cathedra hereditaria ${ }^{15}$. Wyjątkowe miejsce wśród apostolskich Kościołów zajmuje rzymski, posiadający katedrę Piotra, ustanowioną przez Chrystusa i nadaną Piotrowi w dniu wypowiedzenia przez Zbawiciela słów: „Tyś jest Opoka”. Ta katedra jest zawsze obecna w Rzymie dzięki sukcesji następców Księcia Apostołów ${ }^{16}$. Tak jak istnieje organiczna jedność między św. Piotrem - głową pozostałych Apostołów, a nimi tworzącymi jedno Kolegium, tak też silna jest jedność między biskupem Rzymu, a pozostałymi biskupami. W oczach Optata istnieje zatem tylko jedna siedziba, mianowicie Piotra $\mathrm{i}$ jego następców. $Z$ nia łączą się pozostałe siedziby biskupów w ten sposób, że tworzą jedną nierozerwalną całośćn ${ }^{17}$. Usiłowania donatystów, by założyć swoją siedzibę w Rzymie, były tylko żałosną farsą nie tylko dlatego, że brak jej było apostolskiego pochodzenia, ale także dlatego, że katedra Piotrowa była jedna jedyna, stanowiąc fons-vivus i radix-arbor pierwotnej jedyności ${ }^{18}$.

Do tej pory Optat powtarzał niejako naukę św. Cypriana o tym, że Piotr został ustanowiony biskupem przez samego Zbawiciela z władzą apostolską i katedrą, później przekazaną Apostołom i mocą sukcesji wszystkim biskupom $^{19}$. Teraz św. Optat czyni krok naprzód, mianowicie opierając się na tekście Mt 16, 19 stwierdza i to wielokrotnie, że jedynie Piotr otrzymał od Chrystusa katedrę z przynależną jej władzą kluczy ${ }^{20}$. Otrzymanie katedry nie jest

${ }^{14}$ De praescriptione haereticorum 21, 4, CCL 1, 202.

15 Por. Contra Donatistas I 15, 2, SCh 412, 206.

${ }^{16}$ Por. tamże II 3, 1-2, SCh 412, 244-266: „Ergo cathedram unicam, quae est prima de dotibus, sedit prior Petrus cui successit Linus; Lino successit Clemens... Damaso Siricius, hodie qui noster et socius. Cum quo nobis totus orbis commercio formatarum in una communionis societate concordat".

17 Por. Zmire, dz. cyt., s. 44.

18 Widać tu wyraźną zależnosć myśli Optata od Cypriana, por. Zmire, dz. cyt., s. 47.

19 Por. Cyprianus, Epistolae 73, 7; 75, 16; M. Maccarrone, Vicarius Christi. Storia del titolo, Roma 1952 (= „Lateranum” 18:1952, 1-320), s. 31; Zmire, dz. cyt., s. 35.

${ }^{20}$ Por. Contra Donatistas VII 3, 3, SCh 413, 222: „Tamen bono unitatis beatus Petrus cui satis erat si post quod negavit, solam veniam consequeretur et praeferri apostolis omnibus meruit et 
tylko faktem historycznym, mającym miejsce w przeszłości, czy jakąś abstrakcją teologiczną, lecz rzeczywistością trwałą w Kościele, jego pierwszym darem. Owa jedyna katedra zabezpieczała jedność Kolegium Apostolskiego i ta jej funkcja wiecznie trwa strzegąc jedności całego Kościoła ${ }^{21}$. Precyzując swoją myśl biskup z Milewy powiada, że przez fakt, iz Piotr - głowa Apostołów sprawował swą władzę w Rzymie, to i w jego następcach zachowana zostaje ciągłość katedry, dzięki której mają oni tę samą pozycję wobec pozostałych biskupów w Kościele, co Piotr wobec Apostołów ${ }^{22}$. Na potwierdzenie tego faktu podaje Optat listę następców św. Piotra sięgającą aż do papieża Syrycjusza, z którym katolicy z Afryki pozostają we wspólnocie. Każdy, kto nie jest w łączności z katedrą Piotra w Rzymie, przestaje być biskupem, bo posiada inną katedrę, fałszywą, obcą prawdziwemu Kościołowi, bo oderwaną od tej jedynej rzymskiej, ustanowionej przez Zbawiciela jako pierwszy dar dla swej Oblubienicy. Od początku zatem donatyści są odłączeni od katedry Piotra, bo zrywając więź z prawowiernym biskupem Cecylianem, zerwali ją z katedrą w Rzymie, a z tą pozostawał w jedności Cecylian - prawowierny biskup Kartaginy $^{23}$. A zatem w przeciwieństwie do pozornej katedry donatystów, Optat i katoliccy biskupi afrykańscy mogą chlubić się posiadaniem rzeczywistej, prawdziwej katedry, gdyż są $\mathrm{w}$ jedności z biskupem Rzymu. I przez to mogą dojść jej początku, a ten jest w Piotrze. Tą głęboką i śmiałą myślą teologiczną żłobi zatem biskup z Milewy eklezjologię drugiej połowy IV wieku stwierdzając

claves regni caelorum communicandas ceteris solus accepit". Optat wyraźnie kładzie nacisk na jednoczesność otrzymania władzy kluczy i katedry przez Piotra, przy czym katedra bardziej uwyraźnia tę władzę, gdyż ma swoje precyzyjnie określone miejsce w Rzymie i w sprawowanym urzędzie biskupa Wiecznego Miasta, zob. Maccarrone, Apostolicità, s. 218 i 226.

21 Por. przypis 6.

22 Por. Contra Donatistas II 2, 2 - 3, 1, SCh 412, 244-246: „Igitur negare non potes scire te in urbe Roma Petro primo cathedram episcopalem esse collatam, in qua sederit omnium apostolorum caput Petrus, unde et Cephas est appellatus, in qua una cathedra unitas ab omnibus servaretur ne ceteri apostoli singulas sibi quisque defenderent ut iam schismaticus et peccator esset qui contra singularem cathedram alteram collocaret. Ergo cathedram unicam quae est prima de dotibus sedit prior Petrus cui successit Linus; Lino successit Clemens [...] Damaso Siricius, hodie qui noster est socius", zob. Y.M.J. Congar, Cephas - Céphale - Caput, "Revue du Moyen Âge Latin" 8(1952) 25. Zdaniem Congara, Optat jako pierwszy zasugerowal ścisłą więź między caput a cephas. Nie jest to zwykłe thumaczenie słowa z języka greckiego na laciński, lecz podkreślenie, ze Piotr został nazwany skałą ( le catholicisme, Paris 1909, 102; C. Petri, Roma christiana, Paris 1976, 272-295; J. Colson, La collégialité chez Irénée et l'Ephese établee au „centre du monde”, w: L'épiscopat catholique. Collégialité et primauté dans les trois premiers siècles de l'Église, Paris 1963, 62.

23 Por. Contra Donatistas I 10, 5, SCh 412, 194: „Non enim Caecilianus exivit a Maiorino avo tuo sed Maiorinus a Caeciliano. Nec Caecilianus recessit a cathedra Petri vel Cypriani sed Maiorinus cuius tu cathedram sedes, quae ante ipsum Maiorinum originem non habet". Spór, jaki powstał wśód biskupów Afryki wokół konsekracji Cecyliana - biskupa Kartaginy, został rozstrzygnięty w 313 r. na jego korzyść przez synod rzymski pod przewodnictwem papieza Milcjadesa. Dla Optata decyzja synodu była rozstrzygająca. 
i o swojej katedrze iście po rzymsku: „per Petrum nostram esse”24' Nic zatem dziwnego, że donatyści szukali sposobu, by pokazać, iż także oni mają udział w katedrze Piotrowej. Nie mogąc pochwalić się łącznością z biskupem Rzymu, którego prawowierność odrzucali, usiłowali ustanowić w Wiecznym Mieście swojego, w osobie niejakiego Makrobiusza i jego kilku następców ${ }^{25}$. To swoiste parodiowanie następców św. Piotra w Rzymie Optat odrzuca, wykazując śmieszność podobnych usiłowań, bowiem za katolikami stoi ścisła więź z Piotrem i Pawłem, którzy przelewając krew za Chrystusa w Rzymie stali się założycielami Kościola w Rzymie. Wspólnota z tymi dwiema kolumnami jest rzeczywistym dowodem prawdziwości Kościoła. Makrobiusz zaś i jego następcy ani nie byli w stanie wykazać się podobną więzią z Apostołami, ani nie mogli brać udziału w celebracji ich wspomnienia wraz z biskupem Rzymu, zasiadającym przecież na katedrze Piotra i sprawującym ten sam urząd, co Książę Apostołów ${ }^{26}$. Ten namacalny dowód braku jedności z katedrą Piotra w postaci niemożności uczestniczenia w oficjalnych obrzędach nad grobami Apostołów przez donatystów, wykorzystał Optat do przysłowiowego postawienia kropki nad ,i" w nauce o prymacjalnej roli biskupa Rzymu w Kościele powszechnym. Wychodząc z tekstów biblijnych ukazujących, iż wolą Boga jest, aby był wielbiony po całym świecie, stwierdza, że wypełnia ją tylko Kościół katolicki, który jest rozsiany po całym świecie ${ }^{27}$. Podczas gdy schizma donatystów, oddalona „w zakątku Afryki, w glębi maleńkiego regionu" ${ }^{28}$, nie mogła pretendować do katolickości, czyli bycia uniwersalną, to katolicki Kościół pozostawal „w łączności z całym światem" 29 . Ten argument geograficzny na rzecz katolickości Kościoła, aczkolwiek istotny w eklezjologii Optata, nie wystarczał. Należało go uzupełnić pojęciami jedności i pokoju (pax i unitas), jakie panują pośród członków prawdziwego Kościoła, a zwłaszcza między biskupami, reprezentującymi lokalne wspólnoty ${ }^{30}$. One są rozumiane przez Optata przede wszystkim

24 Tamże II 6, 1, SCh 412, 256; Maccarrone, Apostolicità, episcopato e primato di Pietro, s. 234.

${ }^{25}$ Por. Contra Donatistas II 4; Monachino, dz. cyt., s. 34-35; Labrousse, dz. cyt., s. 114.

26 Por. Contra Donatistas II 4, 1, SCh 412, 246: „Sed et habere vos in urbe Roma partem aliquam dicitis; ramus est vestri erroris, protentus de mendacio, non de radice veritatis. Denique si Macrobio dicatur ubi illic sedeat, numquid potest dicere in cathedra Petri? Quam nescio si vel oculis novit, et ad cuius memoriam non accedit quasi schismaticus contra apostolum faciens, qui ait: memoriis sanctorum communicantes. Ecce praesentes sunt ibi duorum memoriae apostolorum. Dicite si ad has ingredi potuit aut obtulit illic ubi sanctorum memorias esse constat. Ergo restat ut fateatur socius vester Macrobius se ibi sedere ubi aliquando sedit Encolpius", zob. J. Ruyschaert, La légendaire „sedes” pétrinienne du Majus, RAC 49 (1973) 297-299; także Maccarrone, Apostolicità, episcopato e primato di Pietro, s. 235.

${ }_{27}$ Contra Donatistas II 12,2 , SCh 412,266 : „in toto terrarum orbe diffusa”.

28 Tamże II 1, 3, SCh 412, 236: ,in particula Africae, in angulo parvae regionis".

29 Tamze VII 5, 1, SCh 413, 234: ,in una communione esse cum toto orbe terrarum".

$30 \mathrm{Za}$ niewystarczalnością aspektu geograficznego powszechności Kościoła przemawiala choćby rzeczywistość na Wschodzie, gdzie mniej więcej w tym samym czasie dominował aria- 
jako jedność moralna lub społeczna Kościoła. Braterstwo między biskupami wyraża się przez wymianę „listów jedności” (formatae), które są czymś więcej niż li tylko prostą, ludzką więzią. Wymiana tych listów jest dowodem prawowitości i przynależności do Kościoła uniwersalnego ${ }^{31}$. Gwarancją autentycznej więzi braterskiej pozostaje jedność z katedrą św. Piotra w Rzymie, bowiem listy jedności wymieniane między biskupami przechodzą przez centrum ich wspólnoty, czyli przez biskupa Rzymu. Sw. Optat w cytowanym zdaniu: "cum quo nobis totus orbis commercio formatarum in una communionis societate concordat", które odnosi do papieża Syrycjusza, wyraźnie podkreśla, że zwornikiem i gwarantem moralnej jedności biskupów jest każdorazowy papież dzierżący katedrę Piotra ${ }^{32}$. Potwierdza tę główną rolę następcy Księcia Apostołów w kolejnym fragmencie swego dzieła, gdzie wyraźnie wskazuje, iż Piotr stanowi centrum jedności katolickiej:

"Quodsi de recipiendis vobis cathedra dubitaret, nonne vos debuistis unitatis adsequi formam? Sed exempla in evangelii lecta proponere noluistis, ut est lectio de persona beatissimi Petri, ex qua forma unitatis retinendae vel faciendae descripta recitatur" ${ }^{33}$.

Mówiąc o świętym Piotrze, ma na myśli Optat biskupa Rzymu, z którym zjednoczenie, przejawiające się w widoczny sposób poprzez wymianę listów, jest ostatecznym kryterium i jedności katolickiej i przynależności do Kościoła katolickiego.

Tak więc wszystko wskazuje na to, że idea katedry Piotra, zaczerpnięta przez Optata z myśli św. Cypriana do walki ze schizmą donatystów, posłużyła mu do ukazania pierwszeństwa Stolicy Rzymskiej w Kościele, jakiego nie posiada żadna inna stolica biskupia. Biskup z Milewy stwierdza, że rzeczywiście Piotr jest głową Apostołów; on otrzymał od Chrystusa katedrę, ,ut unitatis negotium formaretur" ${ }^{34}$. Ona posiada w sobie walor uniwersalny obecny wszędzie tam, gdzie rozprzestrzenił się Kościół katolicki. Będąc symbolem i gwarancją jedności biskupów i Kościoła, ,żyje” w każdorazowym następcy św. Piotra, a zgodność $\mathrm{z}$ nią jest ostatecznym punktem odniesienia dla stwierdzenia prawdziwości Kościoła.

nizm. Optat zdając sobie sprawę z tego, dołączyl do bazy geograficznej aspekt jedności różnych biskupów i wspólnot ze stolicą sw. Piotra w Rzymie, por. Monachino, dz. cyt., s. 32.

31 Por. Contra Donatistas II 3, 2, SCh 412, 246: "Cum quo nobis totus orbis commercio formatarum in una communionis societate concordat"; J. Colson, La collégialité épiscopale. Échanges de correspondance, w: L'épiscopat catholique, s. 33-38.

${ }^{32}$ Por. Contra Donatistas II 3; Batiffol, Cathedra Petri, s. 105-121.

33 Contra Donatistas VII 3; Zmire, dz.cyt., s. 58; Monachino, dz. cyt., s. 35.

${ }^{34}$ Contra Donatistas VII 3. 


\section{SAINT PETER'S CATHEDRAL IN THE TEACHING OF OPTAT FROM MILEW AS THE FINAL CRITERION OF TRUTHFULNESS OF THE CHURCH}

(Summary)

The article Saint Peter's cathedral in the teaching of Optat from Milew as the final criterion of truthfulness of the Church is particularly about certain period in the catholic Church history in IV century, which was experienced in the Latin Africa by schism of the Donatist. In order to prevent the division Saint Optat broadcasted the extremely mature conception of the Saint Peter's cathedral, that was based on Saint Cyprian's idea. Optat describes this cathedral as a first gift for the Church meaning Saint Peter, who is a source of the rest of gifts such as baptism and penance. This cathedral was transmitted to the Saint Peter's successors as a source and tool for the Church union. Everyone who wanted to be in the harmony with me Church should maintain complete union with bishop of Rome. 